\title{
The natural alkaloid Jerantinine $B$ has activity in acute myeloid leukemia cells through a mechanism involving c-Jun
}

\author{
Hayaa Moeed Alhuthali, ${ }^{1,2}$, Tracey D. Bradshaw ${ }^{3}$, Kuan-Hon Lim ${ }^{4}$, Toh-Seok Kam ${ }^{5}$ and Claire H. Seedhouse ${ }^{1 *}$ (D)
}

\begin{abstract}
Background: Acute myeloid leukemia (AML) is a heterogenous hematological malignancy with poor long-term survival. New drugs which improve the outcome of AML patients are urgently required. In this work, the activity and mechanism of action of the cytotoxic indole alkaloid Jerantinine B (JB), was examined in AML cells.

Methods: We used a combination of proliferation and apoptosis assays to assess the effect of JB on AML cell lines and patient samples, with $\mathrm{BH} 3$ profiling being performed to identify early effects of the drug ( $4 \mathrm{~h})$. Phosphokinase arrays were adopted to identify potential driver proteins in the cellular response to $\mathrm{JB}$, the results of which were confirmed and extended using western blotting and inhibitor assays and measuring levels of reactive oxygen species.

Results: AML cell growth was significantly impaired following JB exposure in a dose-dependent manner; potent colony inhibition of primary patient cells was also observed. An apoptotic mode of death was demonstrated using Annexin $V$ and upregulation of apoptotic biomarkers (active caspase 3 and cleaved PARP). Using BH3 profiling, JB was shown to prime cells to apoptosis at an early time point $(4 \mathrm{~h})$ and phospho-kinase arrays demonstrated this to be associated with a strong upregulation and activation of both total and phosphorylated c-Jun (S63). The mechanism of c-Jun activation was probed and significant induction of reactive oxygen species (ROS) was demonstrated which resulted in an increase in the DNA damage response marker $\mathrm{YH} 2 \mathrm{AX}$. This was further verified by the loss of JB-induced C-Jun activation and maintenance of cell viability when using the ROS scavenger N-acetyl-L-cysteine (NAC).
\end{abstract}

Conclusions: This work provides the first evidence of cytotoxicity of JB against AML cells and identifies ROSinduced c-Jun activation as the major mechanism of action.

Keywords: Acute myeloid leukemia, Jerantinine, c-Jun, reactive oxygen species

\section{Background}

Acute myeloid leukemia is an aggressive heterogeneous clonal disorder of hematopoietic stem cells. It is characterized by defects in the self-renewal and differentiation programs that regulate myeloid cell production causing accumulation of immature, non-functional cells termed myeloblasts. Despite advances in the outcome of younger

\footnotetext{
* Correspondence: Claire.seedhouse@nottingham.ac.uk

'Blood Cancer and Stem Cells, Division of Cancer and Stem Cells, School of Medicine, Nottingham Biodiscovery Institute, University of Nottingham, Room B209, University Park, Nottingham NG7 2RD, UK

Full list of author information is available at the end of the article
}

AML patients, long-term remission is still not achieved in the majority of cases and AML in the elderly, which is often correlated with adverse risk factors, is associated with poor clinical outcome [1]. Whilst initial clinical results in patients treated with small molecule inhibitors are promising, relapse often occurs due to the emergence of acquired resistance mechanisms; there therefore remains an unmet need for drugs acting on other signaling pathways.

Natural products represent important sources of drugs and drug-scaffolds, and natural product-inspired therapies

C C The Author(s). 2020 Open Access This article is licensed under a Creative Commons Attribution 4.0 International License, which permits use, sharing, adaptation, distribution and reproduction in any medium or format, as long as you give appropriate credit to the original author(s) and the source, provide a link to the Creative Commons licence, and indicate if changes were made. The images or other third party material in this article are included in the article's Creative Commons licence, unless indicated otherwise in a credit line to the material. If material is not included in the article's Creative Commons licence and your intended use is not permitted by statutory regulation or exceeds the permitted use, you will need to obtain permission directly from the copyright holder. To view a copy of this licence, visit http://creativecommons.org/licenses/by/4.0/ The Creative Commons Public Domain Dedication waiver (http://creativecommons.org/publicdomain/zero/1.0/) applies to the data made available in this article, unless otherwise stated in a credit line to the data. 
continue to have significant impact in the cancer arena [2]. Work by Lim et al. [3] on the leaf extracts of the Malayan plant Tabernaemontana corymbosa resulted in the isolation and purification of a series of new alkaloids, the Jerantinines, which have demonstrated promising biological activity. The majority of published work has been on Jerantinines A and B (JA and JB), reporting in vitro antitumor activities of these agents against various solid human-derived carcinomas. Specifically, JA and JB have been shown to inhibit the growth and colony formation of cancer cell lines accompanied by induction of apoptosis in a dose- and time-dependent manner $[4,5]$. JA and JB potently inhibited tubulin polymerization and caused severe perturbation of microtubule dynamicity $[4,5]$. X-ray crystallography studies demonstrated the colchicine site as the binding site of JB acetate (JBa) on microtubules [6].

$\mathrm{JA}$ and JB were also found to inhibit the activity of kinases involved in mitosis and significantly evoke potent G2/M cell cycle arrest with PLK1 being targeted in a dose-dependent manner [5]. An additional mechanism of action in non-hematological cancers included modulation of splicing [7].

These findings encouraged us to assess JB activity in AML cells, with the aims of establishing whether this natural product would provide potential effective targeting of AML and to elucidate the main mechanism of drug action in AML cells.

\section{Methods}

Materials

$10 \mathrm{mM}$ stocks of JB and JBa were stored in dimethyl sulphoxide (DMSO) at $-80^{\circ} \mathrm{C}$ protected from light. Unless otherwise stated $\mathrm{IC}_{50} \mathrm{JB}$ concentrations were used.

\section{AML cell lines and primary samples}

MV4-11 and HL-60 myeloid leukemia cell lines were grown in Roswell Park Memorial Institute (RPMI-1640) medium supplemented with $10 \%$ fetal calf serum (FCS: 02-00-850; First Link), $2 \mathrm{mM} \mathrm{L-glutamine} \mathrm{(G7513,}$ Sigma), $10 \mu \mathrm{g} / \mathrm{ml}$ streptomycin and $100 \mathrm{U} / \mathrm{ml}$ penicillin. KG-1a cell line was cultured as above but supplemented with 20\% FCS. MV4-11 was purchased from the American Tissue Culture Collection (Manassas, USA). HL-60 and KG1a were purchased from the European Collection of Animal Cell Culture (Salisbury, UK). All cells were incubated at $37{ }^{\circ} \mathrm{C}$ in $5 \% \mathrm{CO}_{2}$ and assays were set up using cells in the log phase of growth. Continued testing to authenticate these cell lines was performed using multiplex short tandem repeat analysis (Powerplex 16, Promega) and mycoplasma testing was carried out routinely using the Mycoalert mycoplasma detection kit (Lonza).
Blood or bone marrow samples were obtained from AML patients presenting to Nottingham University Hospital following informed consent. Mononuclear cells were isolated from AML patient samples using a standard density gradient/centrifugation method and clonogenic assays were carried as previously described using $2 \times 10^{4}$ cells per well. Growth was defined by the presence of $>12$ colonies in untreated conditions [8].

\section{Cell viability assays}

Cell viability was initially assessed using Alamar Blue (AbD Serotec) according to the manufacturer's instructions. Cell counting using a hemocytometer was also undertaken.

Apoptosis was examined using the Annexin V-FITC apoptosis detection kit (Trevigen) according to manufacturer's instructions. Cleaved PARP was measured in cells fixed in 4\% paraformaldehyde using Alexa Fluor 647 Conjugate (BD Biosciences). Analyzes were performed by flow cytometry using a FACS Canto II (BD Biosciences). Assessment of activated caspase was made on cells fixed and permeabilized using a Leucoperm kit (AbD Serotec), active caspase 3 was measured using PEconjugated polyclonal rabbit anti-active caspase-3 (BD Pharmingen).

\section{Dynamic BH3 profiling}

Cells at $5 \times 10^{5} / \mathrm{ml}$ were incubated with the $\mathrm{IC}_{50}$ concentration of JB in culture medium for $4 \mathrm{~h}$. Cytochrome C release was measured as previously described. Adjustments for peptide induced cytochrome $\mathrm{C}$ release in untreated cells were made in order to establish agentspecific release, using the formula 100*(release with agent - release without agent $) /(100$ - release without agent) [9].

\section{Identification of target proteins}

A Proteome Profiler Human Phospho-Array (R\&D Systems) was used to analyze the phosphorylation profile in cells according to the manufacturer's instructions. Results were confirmed using western blot analysis with anti-rabbit total c-Jun (Abcam 32137), anti-rabbit phospho c-Jun (S63) (Abcam 32385) and loading control mouse anti-Lamin (Santa Cruz \# SC-7292). C-jun was probed for first, followed by membrane striping and probing for lamin.

\section{Determination of intracellular ROS}

Cells at a density of $5 \times 10^{5} / \mathrm{ml}$ medium were treated with JB and incubated at $37^{\circ} \mathrm{C}$ for $4 \mathrm{~h}$. Twenty-five mins prior to the end of incubation, $3 \mu \mathrm{M}$ chloromethyl dihydro 2'7'dichlorofluorescein diacetate (CM-H2DCFDA) (Invitrogen) was added to cells. At the completion of incubation, samples were placed on ice and the fluorescent 
oxidation product measured immediately by FACS Canto II flow cytometry. N-Acetyl-L-Cysteine (NAC) and SP600125 JNK inhibitor (JNKI) were purchased from Sigma (A7250) and Abcam (ab120065) respectively. Further dilutions were made in cell culture medium.

\section{Assessment of DNA damage response (DDR) marker (H2AX Ser139)}

H2AX phosphorylation on Ser139 ( $\gamma \mathrm{H} 2 \mathrm{AX})$ was examined by flow cytometry with a kit from Upstate (Millipore cat\# 16-202) according to the manufacturer's instructions.

\section{Statistical analysis}

Statistical analyses were performed using paired T-test. Significance was defined as a $p<0.05$.

\section{Results}

Jerantinine B inhibits the growth of AML cells in a dosedependent manner

The structure of JB is shown in Fig. $1 \mathrm{a} . \mathrm{IC}_{50}$ values were determined at $24 \mathrm{~h}$ exposure to JB for cell lines using alamar blue assay and cell counting. The cell lines demonstrated similar sensitivities with $\mathrm{IC}_{50}$ values: MV4-11 $0.3 \mu \mathrm{M}$; HL-60 0.4 $\mu \mathrm{M}$ and KG1a $0.8 \mu \mathrm{M}$ (Fig. 1b). Due

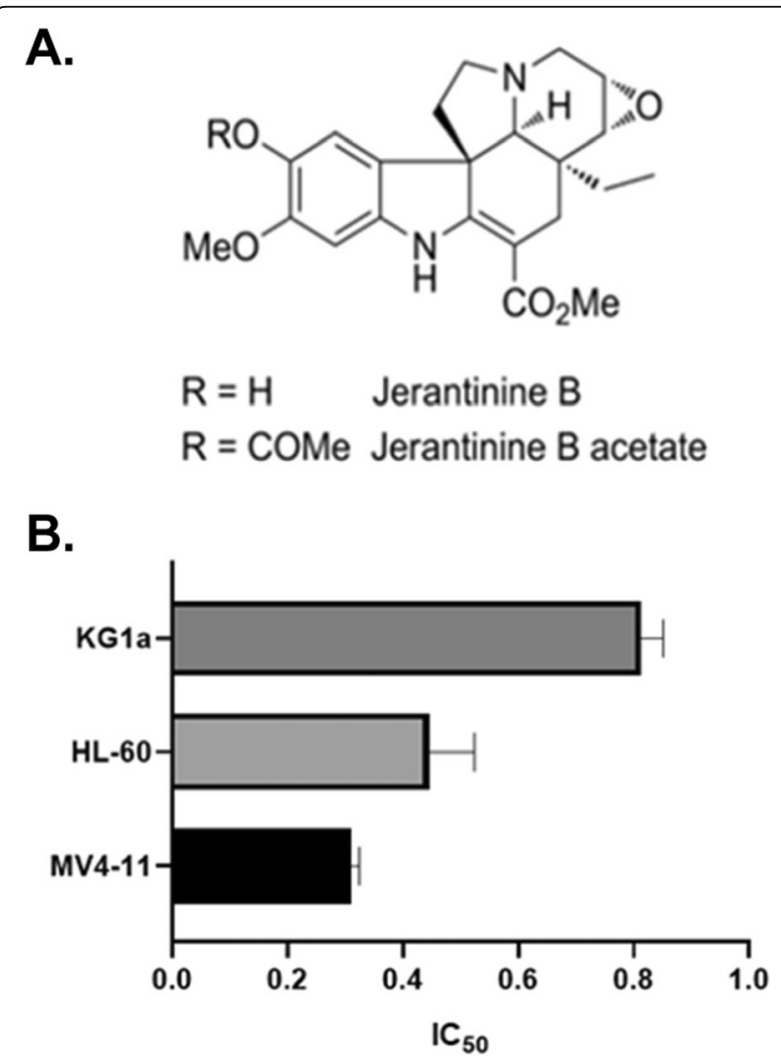

Fig. 1 Cytotoxicity of jerantinine $B$ in $A M L$ cell lines. a. Structure of JB and JBa. b. Mean $I C_{50}$ values of JB at $24 \mathrm{~h}$. Columns, mean of three independent experiments; bars, SD to the comparable drug sensitivities, further assays were not always performed on all three of the cell lines.

Annexin $\mathrm{V}$ assays were performed to establish whether JB induced apoptosis after 24 and $72 \mathrm{~h}$ exposure. Figure $2 \mathrm{a}$ demonstrates significant apoptotic cell death resulting from $\mathrm{IC}_{50}$-JB treatment in all cell lines when compared to untreated controls $(p<0.05)$ in a time-dependent manner. This was particularly profound in the HL-60 cell line at $72 \mathrm{~h}$.

Apoptotic markers were also assessed to further confirm apoptotic cell death in JB-exposed cells. Using MV4-11 and HL-60 cells treated with $\mathrm{IC}_{50} \mathrm{JB}$, active caspase 3 and cleaved PARP apoptotic markers were shown to increase significantly $(p<0.05)$ when compared to untreated controls (Fig. 2b).

JB was shown to affect the cell cycle in AML cell lines and cause transient $\mathrm{G} 2 / \mathrm{M}$ arrest, however the increase was not as profound as in solid cancer cell lines (additional file 1).

\section{JB exerts an early apoptotic effect on AML cells}

BH3 profiling assays on MV4-11 cells demonstrated that JB has an early effect with cells being primed for apoptosis within $4 \mathrm{~h}$. Figure $2 \mathrm{c}$ shows that when using the negative control, mutated PUMA2A peptide, there is no induction of cytochrome $\mathrm{C}$ release, indicating that JB alone does not induce cytochrome $\mathrm{C}$ (and thus apoptosis) at this time point. However, when PUMA-BH3 or $\mathrm{BAD}-\mathrm{BH} 3$ are added, cytochrome $\mathrm{C}$ release occurs indicating that JB has primed the cells to undergo apoptosis.

\section{JB induces c-Jun activation in leukemia cell lines}

A protein kinase array was used to identify changes at the $4 \mathrm{~h}$ time point with prominent phosphorylation seen in the c-Jun/JNK signaling pathway. JB-treated MV4-11 and HL-60 cells exhibited a high level of phosphorylation in JNK1/2/3 and c-Jun S63 compared to the untreated samples (additional file 2). Western blotting confirmed increased levels of total and phosphorylated (S63) c-Jun after $4 \mathrm{~h}$ JB exposure. Figure 3a shows that $4 \mathrm{~h}$ exposure to JB resulted in strong expression of total and phosphorylated c-Jun protein in all cell lines studied.

\section{JB induces reactive oxygen species (ROS)}

C-Jun/JNK has previously reported to be activated in cells exposed to oxidative stress $[10,11]$. ROS levels in JB treated cells were therefore determined at $4 \mathrm{~h}$ using oxidative stress indicator CM-H2DCFDA. In comparison to the control group, $\mathrm{IC}_{50} \mathrm{JB}$ treatment produced significantly increased ROS levels (Fig. 3b). Flow cytometric analysis demonstrated that ROS levels were increased by $2.39(P=0.002), 1.57(P=0.03)$ and 1.70 -fold $(P=0.006)$ in HL-60, MV4-11 and KG1a respectively. Confirmatory assays with HL-60 cells demonstrated that co-treatment 

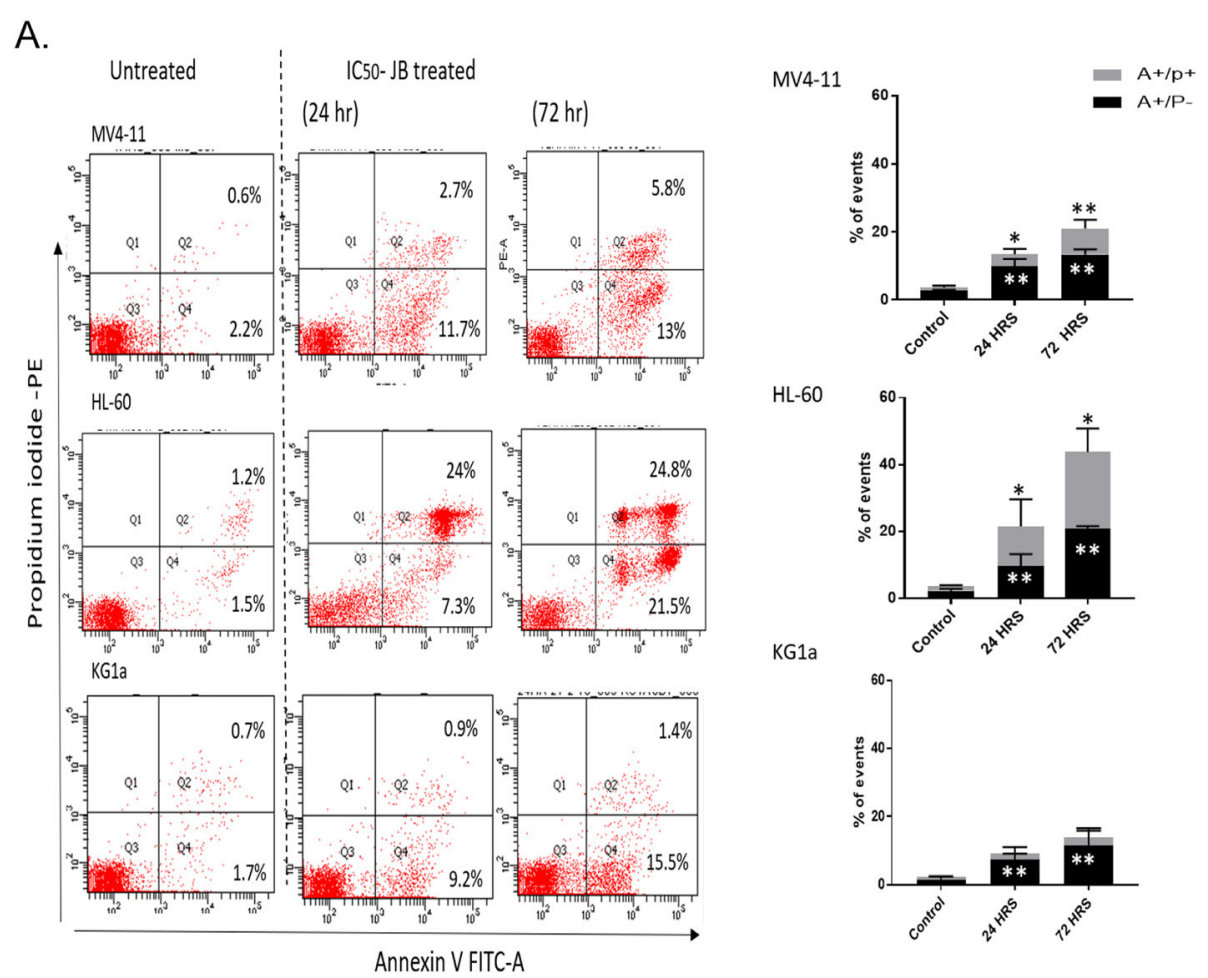

KG1a

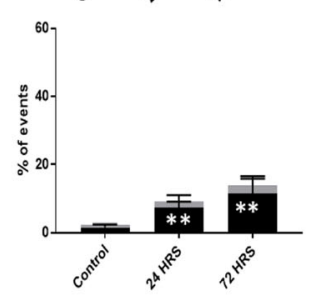

B.

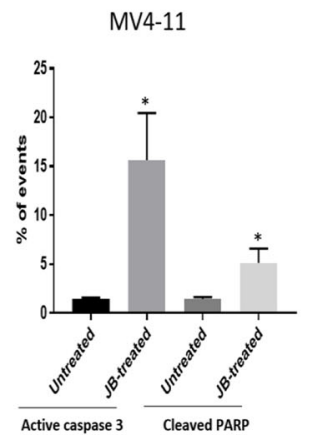

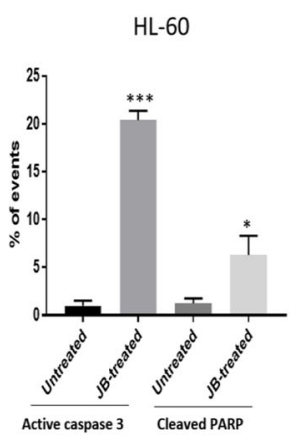

C.

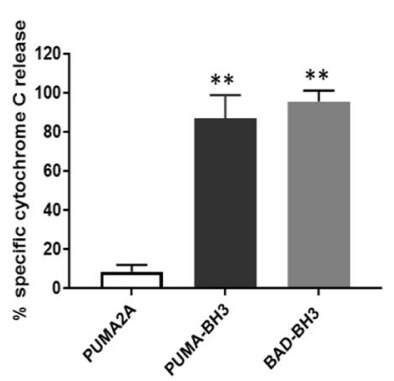

Fig. 2 Induction of apoptosis in $I_{50} J B$ exposed AML cells. a. Flow cytometric analysis of Annexin V/propidium iodide staining following $I C_{50}-J B$ treatment for 24 and $72 \mathrm{~h}$. Representative flow cytometry plots and summary histograms are shown. A+/Pl- indicates cells undergoing early stage apoptosis, while A+/PI+ defines late stage apoptotic populations. b. Summary bar chart of flow cytometric analysis of cleaved PARP and active caspase 3 apoptotic markers following $24 \mathrm{~h} \mathrm{IC} 50$ JB exposure. c. BH3 profiling following $4 \mathrm{~h} \mathrm{IC} \mathrm{I}_{50} \mathrm{JB}$ treatment in MV4-11 cells. Cytochrome $C$ release demonstrates PUMA- and BAD-BH3 peptides prime the cells to apoptosis. PUMA2A is a mutated peptide which acts as a negative control. Columns, mean of at least three independent experiments; bars, SD. ${ }^{*} P<0.05,{ }^{* *} P<0.01,{ }^{* * *} P<0.001$

of cells with JB and the antioxidant NAC abolished JBinduced $\operatorname{ROS}(\mathrm{P}=0.03)$ (Fig. 3b).

\section{Association between ROS generation and c-Jun/JNK activation in JB-induced AML cell death}

Upon establishing that JB generated significant levels of ROS, we aimed to establish whether scavenging of ROS resulted in the inhibition of c-Jun activation following JB-treatment. A JNK inhibitor (JNKI) was used as a positive control. HL-60 cells were pre-incubated with $20 \mu \mathrm{M}$ JNKI for $1 \mathrm{~h}$ to allow JNK inhibition and then treated with JB for up to $24 \mathrm{~h}$. Lysates were prepared after $4 \mathrm{~h}$ of incubation for assessing c-Jun protein expression and cell counting was performed after $24 \mathrm{~h}$ for evaluating cell viability. Immunoblotting results revealed that cotreatment with JB and the antioxidant NAC significantly reduced JB-induced C-Jun activation to levels comparable with the JNKI- JB co-treated sample (Fig. 3c). These data support the involvement of ROS in JB activity. Subsequently, a cell viability assay demonstrated that JBtreated samples exhibited $59.93 \% \pm 9.38$ viability that was increased significantly in JB-NAC and JNKI-JB 
A.

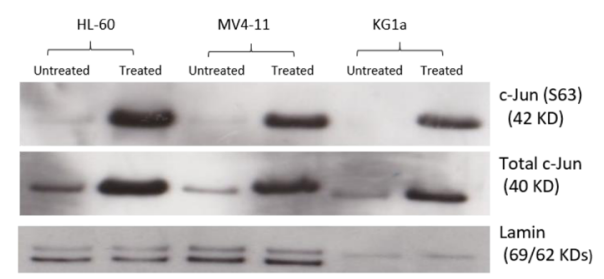

B.
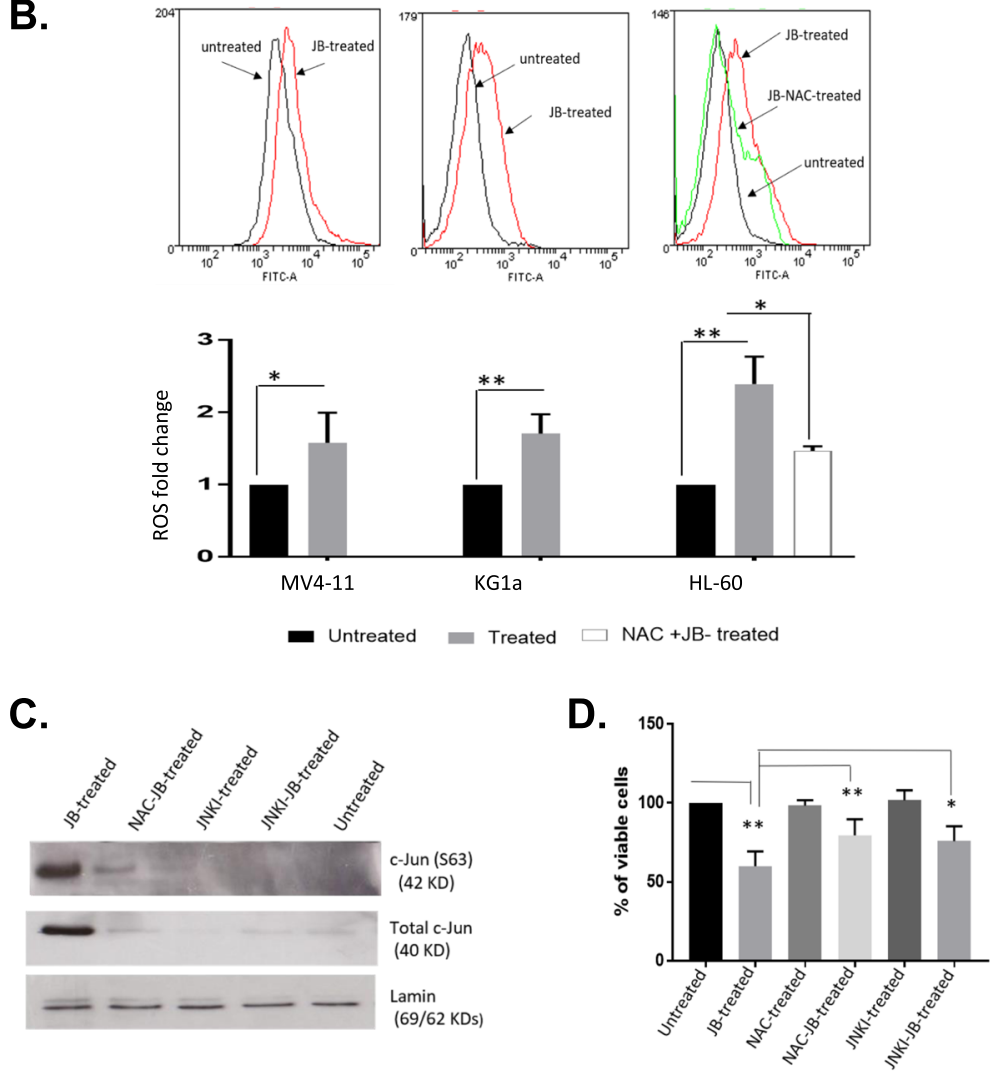

E.

MV4-11

HL-60
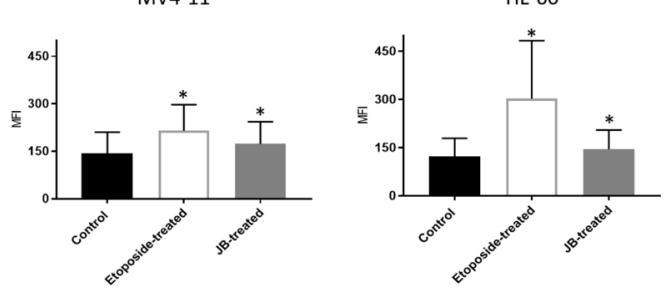

Fig. $3 \mathrm{JB}$ activates c-Jun through ROS induction. a. Western blot (cropped) demonstrating $4 \mathrm{~h}$ JB exposure results in a strong upregulation of total c-Jun and activation of c-Jun ( 563 phosphorylation) in AML cell lines. Lamin is shown as the loading control and the figure is representative of three independent experiments. b. JB induced intracellular ROS in AML cell lines. The bar charts indicate the fold change in median fluorescence intensity compared to untreated controls upon addition of the oxidative stress indicator CM-H2DCFDA, with the elimination of ROS seen when the anti-oxidant NAC is included. Representative flow cytometry plots of ROS measurements are shown above the corresponding bar charts. $\mathbf{c}$. Western blot results (cropped) showing elimination of JB-dependent c-Jun activation by either ROS scavenger or JNKI, representative of three independent experiments. $\mathbf{d}$. cell counts after $24 \mathrm{~h}$ incubation showing a combination of ROS scavenger or JNKI with JB treatment reversed JBinduced cell death, displayed as \% viability of untreated control. e. DNA damage, assessed by the response marker $\mathrm{\gamma H} 2 \mathrm{AX}$, is increased in JBtreated cells. Bars represent the mean of the Median Fluorescence Intensity (MFI) in respect to the negative untreated control. Etoposide was used as a positive control. Columns, mean of at least three independent experiments; bars, SD. ${ }^{*} P<0.05$ and ${ }^{* *} P<0.01$. Full length blots for the westerns in this figure are shown in additional file 3 
treated samples $(P=0.003$ and 0.02 respectively) (Fig. 3d). This suggests that JB-mediated intracellular oxidative stress acts as a signal for c-Jun/JNK-induced death in AML cells.

\section{DNA damage assessment}

Establishing significant generation of ROS by JB led us to evaluate the potential of JB to cause DNA damage. This was investigated by flow cytometric detection of the DNA damage response protein, gamma- $\mathrm{H} 2 \mathrm{AX}(\gamma \mathrm{H} 2 \mathrm{AX})$. Figure 3e represents the measurement of $\gamma \mathrm{H} 2 \mathrm{AX}$ after $4 \mathrm{~h}$ exposure to JB in MV4-11 and HL-60 showing that $\gamma \mathrm{H} 2 \mathrm{AX}$ was significantly increased in both cell lines $(P<$ 0.05). Etoposide, a known inducer of DNA DSBs, was used as a positive control.

$J B$ acetate $(J B a)$ inhibits colony formation of primary AML patient cells

To demonstrate that JB is also effective in primary AML cells, JB acetate (JBa) was tested on four patient samples in clonogenic assays. For this long-term assay, the acetate derivative of JB was used; as it demonstrates increased stability and reduction of overall polarity [3]. Fresh diagnostic AML samples were grown for 14 days in a methylcellulose-based medium containing 0 to $5 \mu \mathrm{M} \mathrm{JBa}$. All samples exhibited sensitivity to JBa and with $\mathrm{IC}_{50}$ values $0.47 \pm 0.11$ (Fig. 4).

\section{Discussion}

In this study, cytotoxicity assays established that JB exhibited potent anti-proliferative activities against AML cell lines accompanied by time- dependent apoptotic cell death. JBa, an acetate derivative of JB, resulted in a dosedependent inhibition of colony formation in primary AML cells indicating cell death or loss of capacity to divide and form progeny colonies. JBa may act as a prodrug with its bio-activation requiring the presence of cellular esterases [12]. As clonogenic assays are performed with a low density of cells, with subsequent low esterase activity, there may be a low bioavailability of the test agent [12], meaning the effects of JBa on AML patient primary cells was potentially underestimated. Importantly, the concentrations used in this work have been demonstrated to be pharmacologically achievable [5].

Results of BH3 profiling assays on MV4-11 cells suggested that JB has an early effect with cells being primed to undergo apoptosis by $4 \mathrm{~h}$. Thus, we examined changes in phosphorylation in an array of protein kinases to identify changes at this time point. This investigation revealed the activation of mitogen-activated protein kinases (MAPKs) in JB-treated cell lines. It specifically established that JB caused strong activation of c-Jun/JNK signaling.

It has been long established that many natural products have pro-oxidant properties [13-15]. The JNK pathway is one of the major signaling cascades of the MAPK signaling pathway that is activated when cells have been exposed to various forms of environmental stress stimuli including ROS. Mitochondrial release of ROS was found to cause JNK activation $[11,16]$. In the current study, we have established the activation of c-Jun/JNK by JB in AML cells through ROS induction. Pharmacological inhibition of JNK confirmed the requirement of activated c-Jun/JNK for JBinduced apoptosis. These findings indicate that the effect of JB in AML cells is dependent on oxidative stress that acts as an early trigger for c-Jun activation, and we suggest that the main molecular targets are via c-Jun/JNK signaling. Indeed, numerous agents with pro-oxidant properties have been shown to be effective against both primary leukemic blasts and leukemic cell lines. It has been reported that clinically achievable concentrations of arsenic trioxide, an agent approved for treating APL has pro-oxidant capacity and mediates apoptosis through three mechanisms: increasing endogenous ROS production, activating MAPKs and also
A.

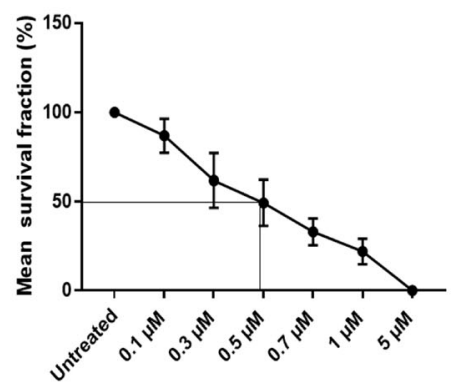

B.

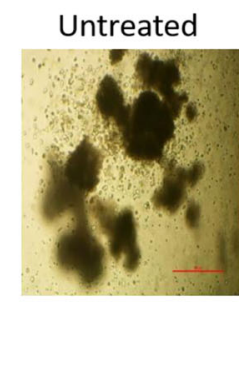

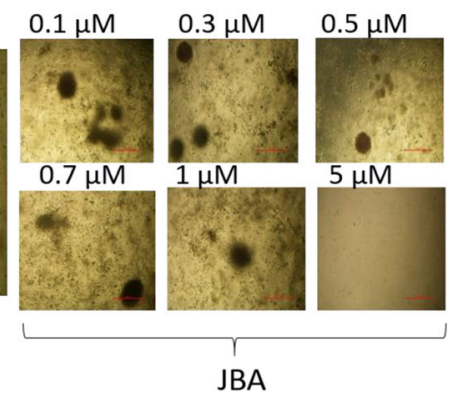

Fig. 4 Effect of $J B$ on colony formation of AML primary cells. a. Survival fraction of four AML patient samples when treated with JB. Results are displayed as mean \pm SD of survival fraction percent. $\mathbf{b}$. Representative images of AML cells from a patient sample showing the effect of JBA on colony formation at a range of drug concentration 
activating caspases in the leukemic cells [17]. In addition, it has been demonstrated that quercetin, a plantderived bioflavonoid, enhances the production of intracellular oxidative stress causing mitochondrial membrane depolarization, cytochrome $\mathrm{C}$ release, sustained activation of ERK and ultimately induction of apoptosis in HL-60 cells in vivo and in vitro [18]. More recently, work has shown that tricetin, a dietary flavonoid in Myrtaceae pollen and eucalyptus honey, induces a JNK- induced apoptosis pathway in the HL60 cell line by enhancing ROS generation, and cotreatment with the ROS scavenger, NAC, abolished tricetin- mediated JNK activation and subsequent cell apoptosis [11].

Increased levels of ROS have previously been shown to perturb cell cycle dynamics, causing G2 phase arrest [19] and correlate with increased DNA damage. In solid cancer models, JB caused significant G2/M cell cycle arrest accompanied by generation of ROS and detection of $\gamma \mathrm{H} 2 \mathrm{AX}$ [5]. Clinically, the drug Vorinostat has also been reported to induce ROS production and cause DNA damage [20]. Consequently, establishing significant generation of ROS and cell cycle perturbation by JB led us to investigate the potential of JB to cause DNA damage. Measurement of the DDR marker $(\gamma \mathrm{H} 2 \mathrm{AX})$ exhibited a significant increase in both the studied cell lines following $4 \mathrm{~h} \mathrm{JB}$ exposure $(P<0.05)$.
Oxidative stress induction in hematopoietic progenitors and leukaemia cells has been reported to cause myeloid cell differentiation [21]. More recently, and of interest to this work, it has been established that increased ROS levels by phorbol-12-myristate-13-acetate (PMA), activate transcription of differentiation genes in AML cells via the c-Jun/JNK signalling pathway [22]. We have preliminary evidence to suggest that JB induces differentiation in AML cells (data not shown) and this is an avenue we will explore further in future work.

It has previously been reported that microtubule polymerization is the major molecular target affected by JA and JB in solid cancers $[4,5]$. In the current study, the effect of JB on microtubules was not investigated. However, transient G2/M- and S-phase cell cycle blockade (additional file 1) is a key indicator of microtubule disruption and evidence is also available documenting the link between microtubules and the JNK pathway. JNK activity determines the fate of microtubules during their life cycle [23] and the JNK pathway was found to be activated by microtubule inhibitors in a wide variety of cell lines [24] The early phosphorylation of JNK has been reported as a specific mechanism mediating microtubule depolymerization and G2/M arrest [25]. Further work suggests that the activation of JNK is needed for, or contributes to, cell death mediated by microtubule disrupting agents $[24,26,27]$.

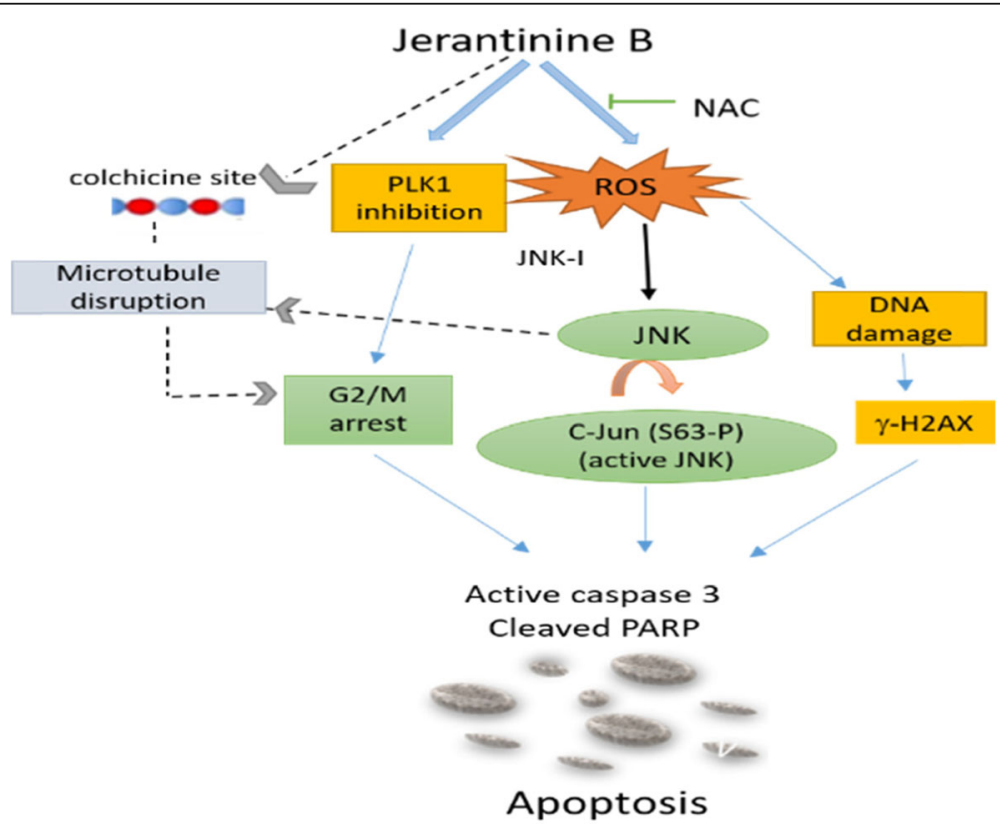

Fig. 5 Suggested mechanism of action of $J B$ in AML cells. JB in AML exerts its effect through increasing ROS level that cause c-Jun/JNK activation as well as DNA damage. JB also targets PLK1 that contributes to G2/M arrest. Activated c-Jun/JNK may contribute to microtubule disruption and ultimately G2/M arrest. JB was reported to bind directly to the colchicine site on microtubule and inhibits microtubule polymerisation but this was not tested in this study 


\section{Conclusion}

Our investigation of this natural product provides the first evidence of cytotoxicity of JB against AML cells and elucidates the mechanism of drug action; this is schematically illustrated in Fig. 5. Thus, JB appears to be a potential chemotherapeutic agent in AML and is worthy of continued development.

\section{Supplementary information}

Supplementary information accompanies this paper at https://doi.org/10. 1186/s12885-020-07119-2.

Additional file 1. Cell cycle analysis following JB treatment. A. Summary histogram illustrating the proportion of cells in each phase of the cell cycle after 4 and $6 \mathrm{~h}$ treatment with $\mathrm{IC}_{50}$ dose of JB. B. example of flow cytometric DNA (7-AAD) content histograms (6 h-JB-treated cells). C. Cell cycle analysis after $24 \mathrm{~h}$ exposure to JB.D. example of flow cytometric analysis at $24 \mathrm{~h}$ showing reduction in BrdU-positive (dividing) cells following JB treatment. Columns, mean of three independent experiments; bars, SD. ${ }^{*} P<0.05$, ${ }^{* *} P<0.01$, ${ }^{* * *} P<0.001$

Additional file 2. Phospho-kinase measurements following $4 \mathrm{~h}$ JB treatment. Pixel densities in A. MV4-11 and B. HL-60 JB-treated cells. Black and grey bars are untreated and treated samples respectively. C. shows the whole film image.

Additional file 3. Representative image of whole film of western blot. 3 : Full image of western blot. A. Full western blot film image for data in Fig. 3a showing upregulation of total and active (S63 phosphorylation) c-Jun following JB treatment. The red boxes indicate where the blot was cropped for Fig. 3a. B. Full length western blot film images for data in Fig. 3c showing elimination of JB-dependent c-Jun activation by either ROS scavenger or JNKI. The red boxes indicate where the blot was cropped for Fig. 3c.

\section{Abbreviations}

AML: Acute myeloid leukemia; CM-H2DCFDA: Chloromethyl dihydro 2' 7'dichlorofluorescein diacetate; DMSO: Dimethyl sulfoxide; FCS: Fetal calf serum; JA: Jerantinine A; JB: Jerantinine B; JBa: Jerantinine B acetate; MFI: Median fluorescence intensity; NAC: N-acetyl-L-cysteine; PARP: Poly (ADP-ribose) polymerase; ROS: Reactive oxygen species; SD: Standard deviation

\section{Acknowledgements}

Not applicable

\section{Authors' contributions}

CHS, HMA and TDB conceived and designed the study. HMA performed the assays and analyzed the data. All authors interpreted the data. HMA and CHS wrote the manuscript and TDB, K-HL and T-SK edited the manuscript. All authors agreed the final version of the manuscript.

\section{Funding}

Dr. Hayaa Alhuthali was funded by The Ministry of Education, Government of Saudi Arabia via a Postgraduate Research Scholarship. Further funding was received from the Nottinghamshire Leukaemia Appeal.

\section{Availability of data and materials}

All data generated or analysed during this study are included in this published article [and its supplementary information files].

\section{Ethics approval and consent to participate}

The East Midlands - Nottingham 1 Research Ethics Committee approved the study protocol (reference 06/Q2403/16). Written informed consent was obtained from the participants for sample collection and analysis in accordance to the Declaration of Helsinki guidelines.

\section{Consent for publication}

Not applicable.

\section{Competing interests}

The authors declare that they have no competing interests.

\section{Author details}

${ }^{1}$ Blood Cancer and Stem Cells, Division of Cancer and Stem Cells, School of Medicine, Nottingham Biodiscovery Institute, University of Nottingham, Room B209, University Park, Nottingham NG7 2RD, UK. ${ }^{2}$ College of Applied Medical Science, Taif University, Ta'if, Saudi Arabia. ${ }^{3}$ School of Pharmacy, University of Nottingham, Nottingham, UK. ${ }^{4}$ School of Pharmacy, University of Nottingham, Semenyih, Malaysia. ${ }^{5}$ Department of Chemistry, University of Malaya, Kuala Lumpur, Malaysia.

Received: 12 March 2020 Accepted: 26 June 2020

Published online: 07 July 2020

\section{References}

1. Dohner H, Estey E, Grimwade D, Amadori S, Appelbaum FR, Buchner T, Dombret H, Ebert BL, Fenaux P, Larson RA, et al. Diagnosis and management of AML in adults: 2017 ELN recommendations from an international expert panel. Blood. 2017;129(4):424-47.

2. Newman DJ, Cragg GM. Natural products as sources of new drugs over the 30 years from 1981 to 2010. J Nat Prod. 2012;75(3):311-35.

3. Lim KH, Hiraku O, Komiyama K, Kam TS. Jerantinines A-G, cytotoxic Aspidosperma alkaloids from Tabernaemontana corymbosa. J Nat Prod. 2008;71(9):1591-4

4. Raja VJ, Lim KH, Leong CO, Kam TS, Bradshaw TD. Novel antitumour indole alkaloid, Jerantinine a, evokes potent G2/M cell cycle arrest targeting microtubules. Investig New Drugs. 2014;32(5):838-50.

5. Qazzaz ME, Raja VJ, Lim KH, Kam TS, Lee JB, Gershkovich P, Bradshaw TD. In vitro anticancer properties and biological evaluation of novel natural alkaloid jerantinine B. Cancer Lett. 2016;370(2):185-97.

6. Smedley CJ, Stanley PA, Qazzaz ME, Prota AE, Olieric N, Collins H, Eastman $\mathrm{H}$, Barrow AS, Lim KH, Kam TS, et al. Sustainable syntheses of (-)-Jerantinines a \& $\mathrm{E}$ and structural characterisation of the Jerantininetubulin complex at the colchicine binding site. Sci Rep. 2018;8(1):10617.

7. Chung FF, Tan PF, Raja VJ, Tan BS, Lim KH, Kam TS, Hii LW, Tan SH, See SJ, Tan YF, et al. Jerantinine a induces tumor-specific cell death through modulation of splicing factor 3b subunit 1 (SF3B1). Sci Rep. 2017;7:42504

8. Grundy M, Seedhouse C, Shang S, Richardson J, Russell N, Pallis M. The FLT3 internal tandem duplication mutation is a secondary target of the aurora B kinase inhibitor AZD1152-HQPA in acute myelogenous leukemia cells. Mol Cancer Ther. 2010;9(3):661-72.

9. Pallis M, Burrows F, Ryan J, Grundy M, Seedhouse C, Abdul-Aziz A, Montero J, Letai A, Russell N. Complementary dynamic BH3 profiles predict cooperativity between the multi-kinase inhibitor TG02 and the $\mathrm{BH} 3$ mimetic ABT-199 in acute myeloid leukaemia cells. Oncotarget. 2017;8(10):16220-32.

10. Hsu YL, Hou MF, Tsai EM, Kuo PL. Tricetin, a dietary flavonoid, induces apoptosis through the reactive oxygen species/c-Jun NH2-terminal kinase pathway in human liver cancer cells. J Agric Food Chem. 2010;58(23): 12547-56.

11. Chien MH, Chow JM, Lee WJ, Chen HY, Tan P, Wen YC, Lin YW, Hsiao PC, Yang SF. Tricetin Induces Apoptosis of Human Leukemic HL-60 Cells through a Reactive Oxygen Species-Mediated c-Jun N-Terminal Kinase Activation Pathway. Int J Mol Sci. 2017;18:8.

12. Rautio J, Kumpulainen H, Heimbach T, Oliyai R, Oh D, Jarvinen T, Savolainen J. Prodrugs: design and clinical applications. Nat Rev Drug Discov. 2008;7(3): 255-70.

13. Asensio-Lopez MC, Soler F, Pascual-Figal D, Fernandez-Belda F, Lax A. Doxorubicin-induced oxidative stress: the protective effect of nicorandil on HL-1 cardiomyocytes. PLoS One. 2017;12(2):e0172803.

14. Groninger E, Meeuwsen-De Boer GJ, De Graaf SS, Kamps WA, De Bont ES. Vincristine induced apoptosis in acute lymphoblastic leukaemia cells: a mitochondrial controlled pathway regulated by reactive oxygen species? Int J Oncol. 2002;21(6):1339-45.

15. Podmore ID, Griffiths HR, Herbert KE, Mistry N, Mistry P, Lunec J. Vitamin C exhibits pro-oxidant properties. Nature. 1998;392(6676):559.

16. Mao X, Yu CR, Li WH, Li WX. Induction of apoptosis by shikonin through a ROS/JNK-mediated process in Bcr/Abl-positive chronic myelogenous leukemia (CML) cells. Cell Res. 2008;18(8):879-88. 
17. Yedjou C, Tchounwou P, Jenkins J, McMurray R. Basic mechanisms of arsenic trioxide (ATO)-induced apoptosis in human leukemia (HL-60) cells. J Hematol Oncol. 2010;3:28.

18. Lee WJ, Hsiao M, Chang JL, Yang SF, Tseng TH, Cheng CW, Chow JM, Lin KH, Lin YW, Liu CC, et al. Quercetin induces mitochondrial-derived apoptosis via reactive oxygen species-mediated ERK activation in $\mathrm{HL}-60$ leukemia cells and xenograft. Arch Toxicol. 2015;89(7):1103-17.

19. Zheng WL, Wang BJ, Wang L, Shan YP, Zou H, Song RL, Wang T, Gu JH, Yuan Y, Liu XZ, et al. ROS-Mediated Cell Cycle Arrest and Apoptosis Induced by Zearalenone in Mouse Sertoli Cells via ER Stress and the ATP/AMPK Pathway. Toxins (Basel). 2018;10:1.

20. Petruccelli LA, Dupere-Richer D, Pettersson F, Retrouvey H, Skoulikas S, Miller WH Jr. Vorinostat induces reactive oxygen species and DNA damage in acute myeloid leukemia cells. PLoS One. 2011;6(6):e20987.

21. Lagadinou ED, Ziros PG, Tsopra OA, Dimas K, Kokkinou D, Thanopoulou E, Karakantza M, Pantazis P, Spyridonidis A, Zoumbos NC. C-Jun N-terminal kinase activation failure is a new mechanism of anthracycline resistance in acute myeloid leukemia. Leukemia. 2008;22(10):1899-908.

22. Lam CF, Yeung HT, Lam YM, Ng RK. Reactive oxygen species activate differentiation gene transcription of acute myeloid leukemia cells via the JNK/C-JUN signaling pathway. Leuk Res. 2018;68:112-9.

23. Daire V, Giustiniani J, Leroy-Gori I, Quesnoit M, Drevensek S, Dimitrov A, Perez F, Pous C. Kinesin-1 regulates microtubule dynamics via a c-Jun N-terminal kinase-dependent mechanism. J Biol Chem. 2009;284(46):31992-2001.

24. Kolomeichuk SN, Terrano DT, Lyle CS, Sabapathy K, Chambers TC. Distinct signaling pathways of microtubule inhibitors--vinblastine and Taxol induce JNK-dependent cell death but through AP-1-dependent and AP-1independent mechanisms, respectively. FEBS J. 2008;275(8):1889-99.

25. Chen J, Sun WL, Wasylyk B, Wang YP, Zheng H. C-Jun N-terminal kinase mediates microtubule-depolymerizing agent-induced microtubule depolymerization and G2/M arrest in MCF-7 breast cancer cells. Anti-Cancer Drugs. 2012;23(1):98-107.

26. Brantley-Finley C, Lyle CS, Du L, Goodwin ME, Hall T, Szwedo D, Kaushal GP, Chambers TC. The JNK, ERK and p53 pathways play distinct roles in apoptosis mediated by the antitumor agents vinblastine, doxorubicin, and etoposide. Biochem Pharmacol. 2003;66(3):459-69.

27. Selimovic D, Hassan M, Haikel Y, Hengge UR. Taxol-induced mitochondrial stress in melanoma cells is mediated by activation of c-Jun N-terminal kinase (JNK) and p38 pathways via uncoupling protein 2. Cell Signal. 2008; 20(2):311-22.

\section{Publisher's Note}

Springer Nature remains neutral with regard to jurisdictional claims in published maps and institutional affiliations.

Ready to submit your research? Choose BMC and benefit from:

- fast, convenient online submission

- thorough peer review by experienced researchers in your field

- rapid publication on acceptance

- support for research data, including large and complex data types

- gold Open Access which fosters wider collaboration and increased citations

- maximum visibility for your research: over $100 \mathrm{M}$ website views per year

At $\mathrm{BMC}$, research is always in progress.

Learn more biomedcentral.com/submissions 